\title{
THE USE OF ARTIFICIAL RESPIRATION IN PULMONARY EM- PHYSEMA ACCOMPANIED BY HIGH CARBON DIOXIDE LEVELS ${ }^{1}$
}

\author{
BY H. J. BOUTOURLINE-YOUNG AND J. L. WHITTENBERGER \\ (From the Department of Physiology, Harvard School of Public Health, Boston, Mass.)
}

(Submitted for publication February 19, 1951; accepted May 23, 1951)

A syndrome resembling carbon dioxide narcosis, which may be precipitated by the administration of oxygen to patients with advanced emphysema, has attracted increasing attention in recent years, although few reports on this subject have appeared in the literature (1-7). A similar response to oxygen has been described by Marshall and Rosenfeld (8) in experimental animals anesthetized with barbiturates or morphine. Marshall and Rosenfeld's analysis provides a basis for understanding the phenomenon in man; in the presence of an increased level of carbon dioxide in the alveolar air and arterial blood, the respiratory center becomes adjusted to the high carbon dioxide pressure, so that carbon dioxide no longer dominates the chemical control of respiration. Such a loss of sensitivity to carbon dioxide in patients with advanced emphysema was demonstrated in 1920 by Scott (9). In the presence of high levels of carbon dioxide and diminished responsiveness of the respiratory center, the principal stimulus to breathing arises from the effects of hypoxia on the carotid body and aortic chemoreceptors. When the stimulus is removed by relief of the hypoxia through oxygen administration, the driving mechanism is weakened or absent, and pulmonary ventilation falls.

The reduction of ventilation induced by oxygen administration results in further accumulation of carbon dioxide in the body, and since excessive levels of carbon dioxide not only fail to stimulate breathing but actually depress it (10-12), the disease may proceed to a fatal outcome due partially at least to the depressing and narcotic effects of carbon dioxide.

The dilemma presented when an obviously cyanotic patient becomes apneic or almost apneic and comatose when given oxygen has been considered a difficult therapeutic problem. Various

1 Aided by a contract between the Medical Division, Chemical Corps, U. S. Army, and Harvard University. recommendations have included the use of carbon dioxide-oxygen mixtures, and, more commonly, the use of relatively low concentrations of oxygen, in the range of 30 to 40 per cent. Evidence will be presented in this report that the prime need of such patients is the elimination of carbon dioxide by increased lung ventilation, and that restored sensitivity to carbon dioxide may be, at least in some patients, of lasting benefit.

Consideration of the use of mechanical aids to respiration in emphysema patients raises the question of the choice of method. There is no ideal method of treatment at this stage of the disease, as such patients are critically ill and understandably intolerant of any procedure which disturbs their already labored breathing. Since there is usually an element of airway obstruction in emphysema, it would be theoretically desirable to apply pressure to assist expiration and inspiration with the timing determined by and precisely dependent on the patient's own respiratory efforts. Such an apparatus, even if available, would have to be applied by a mask or hood; the difficulties encountered in obtaining the necessary tightness of fit for prolonged periods in such patients are often insurmountable.

An alternative method is to enclose the patient's body in a respirator, for the use of negative pressure around the body to assist inspiration and positive pressure around the body to assist expiration. The advantages of this method are that the head is free and that a wide range of pressures can be attained. The disadvantages are that the respirator attempts to set the rhythm of breathing, the patient must be recumbent, and nursing care is impeded. A theoretic advantage of the respirator is that a continuous positive pressure could be used within the tank, reducing the lung volume to a point where the inspiratory muscles could work more effectively.

This report describes the use of the body res- 
pirator in two patients with severe emphysema accompanied by high carbon dioxide levels. A report is made at present for two reasons : 1 ) an adequate number of cases for studies of this type is difficult to obtain ; 2) although results were disappointing in one patient, the effects on the other were so dramatic that recommendation for further trial of the therapeutic procedure seemed warranted.

\section{MATERIAL AND METHODS}

Patient 1 (N. G.) was a 58 year old white male candyworker, admitted to the Peter Bent Brigham Hospital on February 1, 1950, with a history of persistent headache, somnolence, dyspnea on exertion, and ankle edema. His first admission was in 1947, with similar complaints. The patient was at that time found to have marked emphysema with secondary polycythemia; he had an arterial oxygen saturation of 82 per cent, and mild cor pulmonale. Cardiac output was 7.3 liters per minute, and the findings suggested early right heart failure. Pneumotachograms at that time showed a pattern of respiration characteristic of marked emphysema, with a minute volume of 6.9 liters per minute. Investigations to determine the cause of the somnolence were not rewarding, and it was concluded that this symptom was due to cerebral hypoxia. An isolated measurement of carbon dioxide serum level was $29 \mathrm{mM}$ per liter.

Since 1947 the patient continued to work, with frequent phlebotomies to control headaches, but his symptoms increased in severity before this admission. When in the outpatient department he had marked somnolence and mental confusion; he was very cyanotic with slow shallow respirations and $2+$ ankle edema.

Family history and past history were non-contributory except for respiratory symptoms. There had been marked dyspnea on exertion for some years, accompanied by a chronic cough productive of scanty sputum. The patient worked in a coal mine for two years just before World War I.

Findings on admission: The patient was cyanosed, orthopneic, and confused. The temperature was 99.5 , pulse 94, respirations 16, and blood pressure 140/84. Respiration was shallow, with a prolonged expiratory phase. The chest had an emphysematous appearance, with increased anteroposterior diameters. To percussion, the chest was hyperresonant throughout, with no areas of dullness; the diaphragms appeared to be low. There were a few moist râles in both lungs, with occasional musical expiratory rhonchi. No clubbing of the fingers was present. There was some distension of neck veins, and $2+$ swelling of the ankles.

Roentgenograms of the chest showed smooth low diaphragms which moved equally. Lung markings were increased, and costophrenic angles were clear.

The hematocrit was 49.2 per cent on admission, and was reduced to 45 per cent after phlebotomy.
It was observed that when oxygen was given, the patient's condition deteriorated and there was marked reduction in ventilation.

Blood chemistry figures were: blood urea nitrogen 17 to $39 \mathrm{mg}$. per cent, protein $6.1 \mathrm{gm}$. per cent, sugar 71 to $93 \mathrm{mg}$. per cent, serum carbon dioxide 35.3 to $41.4 \mathrm{mM}$ per liter, chlorides 83 to $91 \mathrm{mEq}$, and total base $139 \mathrm{mEq}$.

Patient 2 (J. M.) was a 55 year old white male clerical worker, admitted to the Veterans Administration Hospital, West Roxbury, June 20, 1950, with a history of shortness of breath and wheezing.

This was his fourth admission, the first being in September, 1946, with a diagnosis of emphysema, bronchiectasis, and malnutrition; the second admission was in August, 1948, with a diagnosis of emphysema and right hydronephrosis; and the third was in January, 1949, with a diagnosis of emphysema and a conversion reaction. The presence of emphysema had been recognized for six years. There was increasing dyspnea on exertion, and recently the patient could not take three steps on the level without gasping for breath. $\mathrm{He}$ was obliged to give up work. The dyspnea varied greatly from time to time. There had been a chronic cough with whitish sputum for years and intermittent wheezing. Occasional ankle edema had been present. For three months prior to this admission there was fatigue and increasing weakness.

Past illnesses included influenza in World War I, but nothing else of significance.

Findings on admission: The patient was cyanosed, dyspneic, and apprehensive. The blood pressure was $110 / 60$, and the pulse 96. The chest showed increase of the anterior-posterior diameter, with poor movement. Breath sounds were distant, and the lung fields hyperresonant. No added sounds were heard.

$\mathrm{X}$-ray of the chest showed the diaphragm low and the lung fields emphysematous.

The hematocrit was 61 per cent and the patient had $17 \mathrm{gm}$. per cent hemoglobin. The serology was negative. A white count showed 9,200 per cubic millimeter, with 78 per cent polymorphs. Chemical examination of the blood gave: nonprotein nitrogen $21 \mathrm{mg}$. per cent, glucose $97 \mathrm{mg}$. per cent, chlorides $82 \mathrm{mEq}$, serum carbon dioxide $40 \mathrm{mM}$ per liter. The electrocardiogram showed right ventricular strain. A repeat white blood count gave 8,200 per cubic millimeter, with 63 per cent polymorphs.

Respiratory ventilation measurements were made by means of a Benedict-Roth type recording spirometer. Pneumotachograms were recorded by the instrument described by Silverman and Whittenberger (13). Residual air was measured by a helium dilution method (14). Alveolar air carbon dioxide was measured by an Engelhard thermoconductivity meter after collection of alveolar air with an automatic sampling device (15). Blood gas partial pressures were measured in arterial samples by the microbubble technique of Riley, Proemmel, and Franke (16). On some samples the Van Slyke-Neill technique was used for oxygen content and capacity and carbon dioxide content (17). 
TABLE I

Analysis of arterial blood samples before respirator treatment (N. G., February 7, 1950)

\begin{tabular}{|c|c|c|c|c|c|c|c|c|}
\hline Conditions & $\mathrm{pO}_{2}$ & $\mathrm{pCO}_{2}$ & Serum $\mathrm{CO}_{2}$ & pH & $\mathrm{O}_{2}$ content & $\mathrm{O}_{2}$ capacity & O2 saturation & $\mathrm{CO}_{2}$ content \\
\hline $\begin{array}{l}\text { Room air } \\
100 \% \text { oxygen, } 7 \text { minutes }\end{array}$ & $\begin{array}{c}m m . ~ H g \\
39 \\
118\end{array}$ & $\begin{array}{c}m m . H g \\
67 \\
76\end{array}$ & $\begin{array}{r}\text { rol. \% } \\
94.9 \\
103.0\end{array}$ & $\begin{array}{l}7.41 \\
7.38\end{array}$ & $\begin{array}{c}\text { vol. \% } \\
\text { clotted } \\
16.69^{*}\end{array}$ & $\frac{\text { vol. \% }}{16.74}$ & $\begin{array}{c}\% \\
73.0 \\
99.7\end{array}$ & $\frac{801 . \%}{85.1}$ \\
\hline
\end{tabular}

Hematocrit $41 \%$.

* Not corrected for dissolved oxygen.

\section{RESULTS}

The blood gas data in patient N. G. when he was semicomatose, before respirator treatment, are given in Table I. The arterial $\mathrm{pO}_{2}$ was only 39 $\mathrm{mm} . \mathrm{Hg}$, resulting in a saturation value of 73 per

TABLE II

Ventilation and $\mathrm{pCO}_{2}$ responses to oxygen before respirator treatment $(N . G$.)

\begin{tabular}{|c|c|c|c|c|}
\hline \multirow{2}{*}{ Date } & \multicolumn{2}{|c|}{ Ventilation } & \multicolumn{2}{|c|}{ Alveolar $\mathrm{pCO}_{2}^{*}$} \\
\hline & On room air & On oxygen & On room air & On oxygen \\
\hline $\begin{array}{l}1950 \\
\text { Feb. } 4 \\
\text { Feb. } 6 \\
\text { Feb. } 7\end{array}$ & $\begin{array}{l}\text { liters pe } \\
7.4 \\
7.3 \\
7.8\end{array}$ & $\begin{array}{r}\text { minute } \\
5.2 \\
5.0 \\
5.4\end{array}$ & $\begin{array}{l} \\
66 \\
63 \\
66\end{array}$ & $\begin{array}{cc}\boldsymbol{H g}_{\boldsymbol{g}} & \\
& \mathbf{7 7} \\
& 87 \\
& 78\end{array}$ \\
\hline
\end{tabular}

* Normal $\mathrm{pCO}_{2}$ at sea level is $39 \pm 2 \mathrm{~mm}$. $\mathrm{Hg}$.

cent, at a $\mathrm{pH}$ of 7.41 and $\mathrm{pCO}_{2}$ of $67 \mathrm{~mm}$. Hg. Although the $\mathrm{pCO}_{2}$ was markedly elevated, the carbon dioxide content of serum was correspondingly increased, giving a $\mathrm{pH}$ of 7.41 .
The same table illustrates the deleterious effects of oxygen in such a patient. After seven minutes of breathing cylinder oxygen (open circuit) the $\mathrm{pCO}_{2}$ had increased to $76 \mathrm{~mm}$. $\mathrm{Hg}$. The carbon dioxide content had risen somewhat and the $\mathrm{pH}$ was down to 7.38. The $\mathrm{pO}_{2}$ was, at $118 \mathrm{~mm}$. $\mathrm{Hg}$, sufficient to saturate hemoglobin to the normal value and thus to relieve cyanosis.

The ventilation volumes and alveolar carbon dioxide during the pretreatment phase and during oxygen administration are given in Table II.

Ventilation and alveolar $\mathrm{pCO}_{2}$ data during and after respirator treatment are summarized in Table III. The first measurements were made approximately 18 hours after respirator treatment was started; the high $\mathrm{pCO}_{2}$ in spite of the large minute volume can probably be explained by the fact that the patient "fought" the respirator, breathing rapidly and shallowly on his own (rate 47 per minute), thus having a relatively low rate of effective alveolar ventilation.

On the second day of treatment there was still

TABLE III

Lung ventilation and alveolar carbon dioxide during and after respirator treatment (N.G.)

\begin{tabular}{|c|c|c|c|c|c|}
\hline \multirow{2}{*}{ Date } & \multirow{2}{*}{ Conditions } & \multicolumn{2}{|c|}{ Minute volume } & \multicolumn{2}{|c|}{ Alveolar $\mathrm{pCO}_{2}$} \\
\hline & & Room air & $100 \% \mathrm{O}_{2}$ & Room air & $100 \% \mathrm{O}_{2}$ \\
\hline \begin{tabular}{l}
\multicolumn{1}{c}{1950} \\
Feb. 12 \\
Feb. 13 \\
Feb. 14 \\
Feb. 15 \\
Feb. 15 \\
Feb. 16 \\
Feb. 16 \\
Feb. 17 \\
Feb. 18 \\
Feb. 19 \\
Feb. 20 \\
Feb. 21 \\
Mar. 1 \\
Mar. 15
\end{tabular} & $\begin{array}{l}\text { Entered respirator } \\
\text { In respirator } \\
\text { In respirator } \\
\text { In respirator } \\
\text { Respirator open during observation } \\
\text { Respirator treatment terminated 9:00 a.m. } \\
\text { Out of respirator } \\
\text { Out of respirator } \\
\text { Out of respirator } \\
\text { Out of respirator } \\
\text { Out of respirator } \\
\text { Out of respirator } \\
\text { Out of respirator } \\
\text { Out of respirator }\end{array}$ & $\begin{array}{c}\text { liters } \\
\overline{14.6} \\
13.5 \\
\overline{9.34} \\
\overline{9.1} \\
\overline{13.7} \\
\overline{-} \\
17.8 \\
18.9 \\
13.4\end{array}$ & $\begin{array}{c}\text { liters } \\
= \\
= \\
7.7 \\
\bar{Z} \\
12.42 \\
= \\
\overline{-} \\
17.85 \\
15.0\end{array}$ & $\begin{array}{c}m m . H g \\
55 \\
46 \\
41 \\
46 \\
47 \\
39 \\
38 \\
37 \\
39 \\
38 \\
33 \\
31\end{array}$ & $\begin{array}{c}m m . H g \\
\overline{100 *} \\
52 \\
\frac{46}{2} \\
59 \\
41 \\
= \\
= \\
= \\
-\end{array}$ \\
\hline
\end{tabular}

* Closed glottis and did not co-ordinate with respirator. 
TABLE IV

Arterial blood gases at five days and at $111 / 2$ months following re-acclimatization $(N . G$.

\begin{tabular}{|c|c|c|c|c|c|c|c|c|c|}
\hline Date & Conditions & $\mathrm{pCO}_{2}$ & $\mathrm{pO}_{2}$ & $\begin{array}{c}\text { Serum } \\
\mathrm{CO}_{2}\end{array}$ & pH & $\begin{array}{c}\mathrm{O}_{2} \\
\text { content }\end{array}$ & $\begin{array}{c}\mathrm{O}_{2} \\
\text { capacity }\end{array}$ & $\begin{array}{c}\mathrm{O}_{2} \\
\text { saturation }\end{array}$ & $\begin{array}{c}\mathrm{CO}_{2} \\
\text { content }\end{array}$ \\
\hline $\begin{array}{l}2 / 21 / 50 \\
2 / 21 / 50 \\
1 / 25 / 51\end{array}$ & $\begin{array}{l}\text { Room air } \\
\text { On } 95 \% \mathrm{O}_{2} \text { for } 31 \mathrm{~min} . \\
\text { Room air }\end{array}$ & $\begin{array}{c}m m . H_{\boldsymbol{g}} \\
\mathbf{3 7} \\
\mathbf{3 1} \\
\mathbf{3 7}\end{array}$ & $\begin{array}{c}m m . H g \\
\frac{67}{76}\end{array}$ & $\begin{array}{l}\text { ool. \% } \\
66.42 \\
62.47 \\
64.48\end{array}$ & $\begin{array}{l}7.51 \\
7.54 \\
7.50\end{array}$ & $\begin{array}{l}\text { vol. \% } \\
14.65 \\
17.41 \\
18.97\end{array}$ & $\begin{array}{l}\text { nol. \% } \\
15.66 \\
15.66 \\
20.28\end{array}$ & $\begin{array}{c}\% \\
92.1 \\
109.6 \\
92.4\end{array}$ & $\begin{array}{l}\text { ool. \% } \\
55.12 \\
51.77 \\
53.23\end{array}$ \\
\hline
\end{tabular}

depression of breathing when high oxygen was given, as indicated by the rise in $\mathrm{pCO}_{2}$ from 46 to $52 \mathrm{~mm}$. $\mathrm{Hg}$. Subsequent values for ventilation were high, and were accompanied by reasonably low alveolar $\mathrm{pCO}_{2}$. The high level of carbon diox: ide $(47 \mathrm{~mm} . \mathrm{Hg})$ at the conclusion of respirator treatment was probably due to a sedative drug inadvertently given.

Analysis of arterial blood at intervals of five days and $111 / 2$ months after respirator treatment, with the patient breathing room air or a high oxygen mixture, gave the results found in Table IV. On room air the $\mathrm{pCO}_{2}$ was slightly below normal on both occasions, and the arterial oxygen saturations were 92 per cent. Oxygen administration no longer led to an elevation of $\mathrm{pCO}_{2}$; in fact, ventilation was stimulated during oxygen administration, possibly due to the patient's enthusiasm to demonstrate his ability. It was difficult to obtain "steady state" values at any time because of the patient's enthusiasm; the gas exchange ratio at the time of the last observation was 1.00 , confirming the impression of overbreathing.

Table $\mathrm{V}$ shows the ventilatory response of the patient when a mixture of carbon dioxide and oxygen was administered. Whereas the carbon dioxide mixture depressed ventilation before respirator treatment, the normal augmentatory re- sponse to carbon dioxide was subsequently restored.

Owing to poor co-operation by the patient, the vital capacity and residual air measurements obtained before artificial respiration therapy were regarded as valueless. A maximum breathing capacity of 36 liters per minute was obtained; this

TABLE V

Response of ventilation to $5.25 \%$ carbon dioxide and $94.75 \%$ oxygen (N.G.)

\begin{tabular}{|c|c|c|c|c|}
\hline \multirow{2}{*}{ Date } & \multirow{2}{*}{ Conditions } & \multicolumn{2}{|c|}{$\begin{array}{l}\text { Minute volume } \\
\text { on }\end{array}$} & \multirow{2}{*}{ Remarks } \\
\hline & & $\begin{array}{c}\text { Room } \\
\text { air }\end{array}$ & $\underset{\text { mixture }}{\mathrm{CO}_{2}}$ & \\
\hline 1950 & \multirow{3}{*}{$\begin{array}{l}\text { Pre-respirator } \\
\text { First day post- } \\
\text { respirator } \\
\text { Post-respirator }\end{array}$} & \multicolumn{2}{|c|}{ liters per minute } & \\
\hline $\begin{array}{l}\text { Feb. } 6 \\
\text { Feb. } 16\end{array}$ & & \multirow[t]{2}{*}{$\begin{array}{l}6.9 \\
9.1\end{array}$} & $\begin{array}{r}5.5 \\
11.1\end{array}$ & $\begin{array}{l}\text { Six minutes of inhalation } \\
\text { Two minutes of inhalation }\end{array}$ \\
\hline Feb. 21 & & & $\begin{array}{l}15.5 \\
18.5 \\
20.3\end{array}$ & $\begin{array}{l}\text { Second minute } \\
\text { Third minute } \\
\text { Fourth minute }\end{array}$ \\
\hline
\end{tabular}

measurement also was impaired by the lack of co-operation. Following therapy, vital capacity was measured as 1.86 liters, the residual air 3.66 liters, and maximum breathing capacity 60 liters per minute.

Table VI gives the results of ventilation measurements and alveolar gas analyses made on January 25,1951 , almost one year after respirator

TABLE VI

Observations 111/2 months after respirator treatment (N. G., January 25, 1951)

\begin{tabular}{|c|c|c|c|c|c|}
\hline \multirow{2}{*}{ Gas inhaled } & \multirow{2}{*}{$\begin{array}{c}\text { Minute volume } \\
\text { BTPS }\end{array}$} & \multirow{2}{*}{ Respiratory rate } & \multirow{2}{*}{ Tidal volume } & \multicolumn{2}{|c|}{ Alveolar } \\
\hline & & & & $\mathrm{pCO}_{2}$ & $\mathrm{pO}_{2}$ \\
\hline $\begin{array}{l}\text { Room air } \\
99+\% \text { oxygen for } 10 \text { minutes } \\
5 \% \text { carbon dioxide in air } 3 \text { rd and } 4 \text { th } \\
\text { minutes }\end{array}$ & $\begin{array}{l}\text { liters per min. } \\
11.6 \\
10.0 \\
12.8\end{array}$ & $\begin{array}{l}20 \\
19 \\
19\end{array}$ & $\begin{array}{l}c c . \\
580 \\
526 \\
674\end{array}$ & $\begin{array}{c}m m . ~ H z \\
34 \\
32 \\
50\end{array}$ & $\begin{array}{l}113^{m m . ~ H z} \\
650 \text { (approx.) }\end{array}$ \\
\hline
\end{tabular}

Expired air: $2.55 \% \mathrm{CO}_{2}, 18.38 \% \mathrm{O}_{2}$, R.Q. 1 .

$\mathrm{CO}_{2}$ dead space: $225 \mathrm{cc}$. 


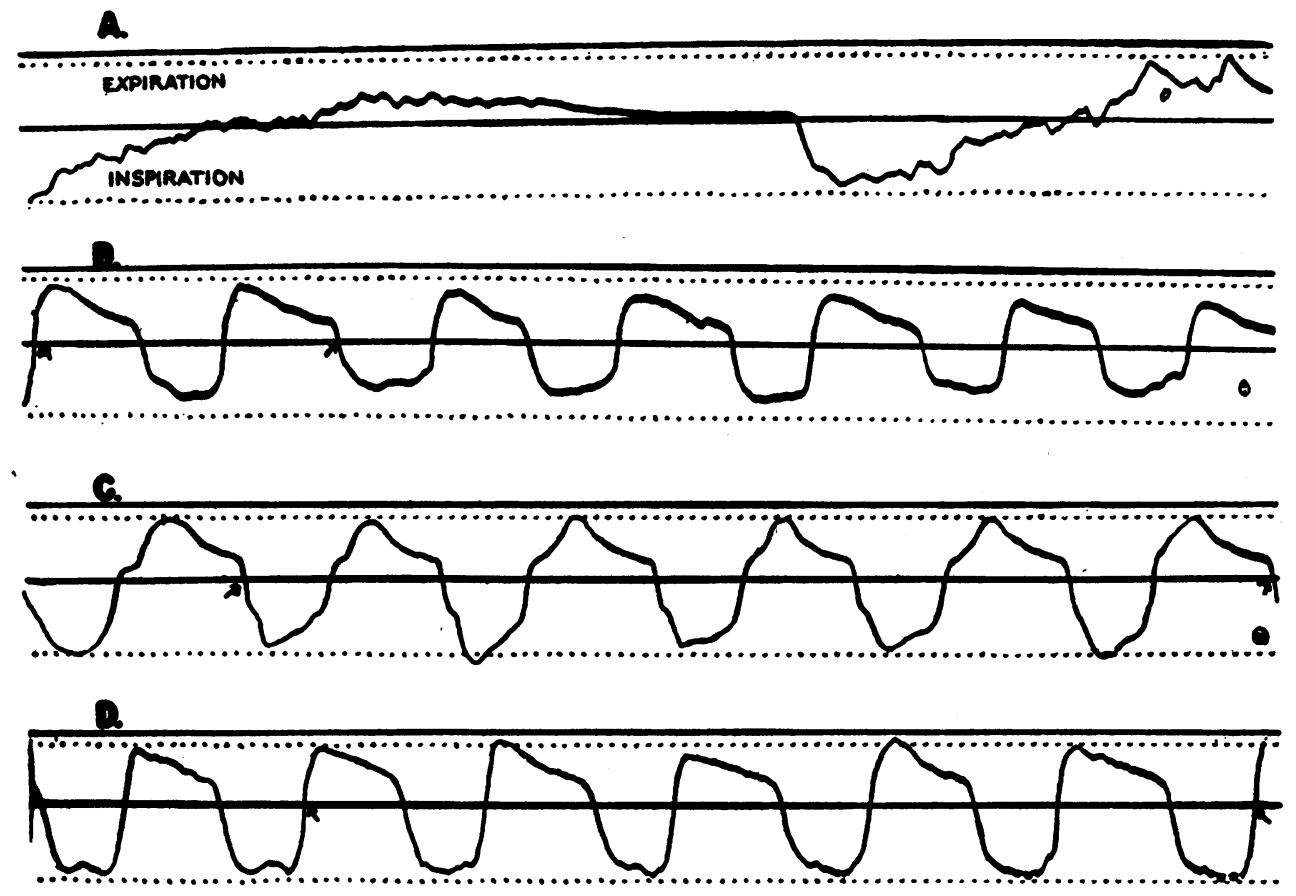

Fig. 1. Instantaneous Air Flow Rate Recordings

$A$. Spontaneous breathing before respirator treatment. Rate very slow; successive expiratory volumes differ, indicating changing midcapacity. Many of superimposed irregularities of pattern are synchronous with heart beat.

$B$. Respirator cycling from $+5 \mathrm{~cm}$. to $-4 \mathrm{~cm} . \mathrm{H}_{2} \mathrm{O}$. Inspiratory pattern changes (below base line) indicate that the patient was not being passively breathed by the respirator. Sustained expiratory flow rate suggests an increased airway resistance.

C. Respirator cycling from +10 to $-12 \mathrm{~cm} . \mathrm{H}_{2} \mathrm{O}$. Pattern of air flow related to known pressure pattern of this type of respirator indicates that the patient is no longer combatting the respirator.

$D$. Spontaneous breathing pattern after respirator treatment. Record is very much like that of $B$ above. Expiratory flow pattern again suggests increased airway resistance and large functional residual volume.

treatment. There was no significant difference between ventilation rates and alveolar $\mathrm{pCO}_{2}$ 's when the patient changed from room air to oxygen breathing. Carbon dioxide administration produced some increment in ventilation, but this represents only the average for the third and fourth minutes, and the observation should have been made for a longer period. In a subsequent test on February 17, 1951, the ventilation increased from a resting value of 8.37 liters per minute to 14.41 liters per minute at the sixth minute of inhalation of 5.16 per cent carbon dioxide in air.

Figure 1 is a pneumotachogram from this patient. The expiratory pattern of air flow is consistent with the presence of emphysema and some degree of obstruction. The irregularities early in the expiratory phase suggest active muscular effort; the prolongation of expiration and sharp fall to base line at the end of expiration suggest the presence of increased airway resistance, which slows flow and increases the amount of air retained in the lungs.

Since leaving the hospital this man progressed satisfactorily. Following a period of rest at home he returned to his job in a candy factory where he has now worked continuously for more than nine months. $\mathrm{He}$ is free of the headaches which were formerly a major symptom, and is able to climb a flight of stairs with only slight dyspnea.

The second patient (J. M.) was found to have an alveolar $\mathrm{pCO}_{2}$ of $66 \mathrm{~mm}$. Hg on July 1, 1950 . Examinations between July 8 and 12 showed ar- 
terial $\mathrm{pCO}_{2}$ values at 51 and $61 \mathrm{~mm}$. $\mathrm{Hg}$ on two occasions, with an alveolar $\mathrm{pCO}_{2}$ averaging 53 $\mathrm{mm}$. $\mathrm{Hg}$. At this time the administration of $90+$ per cent oxygen consistently reduced ventilation by about 25 per cent within five minutes. The minute volume on room air was 6.5 to 7 liters. When high oxygen was given, the alveolar $\mathrm{pCO}_{2}$ rose rapidly to an average of $75 \mathrm{~mm}$. $\mathrm{Hg}$, while the ventilation fell. The arterial $\mathrm{pH}$ at this time was 7.36, falling to 7.23 upon administration of oxygen. The arterial $\mathrm{pO}_{2}$ was consistently 35 to 37 $\mathrm{mm}$. $\mathrm{Hg}$, giving an arterial oxygen saturation of about 65 per cent on room air. Residual air and maximum breathing capacity determinations were valueless because of poor co-operation of the patient. The best measurement of vital capacity was about $900 \mathrm{cc}$. When a mixture of 94.75 per cent oxygen and 5.25 per cent carbon dioxide was administered for five minutes, there was a progressive reduction in ventilation.

Respirator therapy was started on July 12, and continued for five days. A short preliminary treatment period of eight hours had been shown to confer no benefit.

Efforts to increase ventilation proved difficult, even when a pressure change of $30 \mathrm{~cm}$. of water was produced in the respirator and various other devices were employed to encourage breathing. The patient appeared to resist the action of all these devices by skillful use of his glottis. Nevertheless, arterial and alveolar $\mathrm{pCO}_{2}$ showed a downward trend. Three determinations of the alveolar $\mathrm{pCO}_{2}$ averaged $41 \mathrm{~mm}$. $\mathrm{Hg}$ for the period July 14 to 16 . At the same time three determinations of the arterial $\mathrm{pCO}_{2}$ averaged $40 \mathrm{~mm}$. $\mathrm{Hg}$. The alveolar $\mathrm{pO}_{2}$ was $106 \mathrm{~mm}$. $\mathrm{Hg}$ and the arterial $\mathrm{pO}_{2}$ had risen to $55 \mathrm{~mm}$. $\mathrm{Hg}$ (average of four determinations). This gave an arterial-alveolar difference of $51 \mathrm{~mm} . \mathrm{Hg}^{2}$ The arterial oxygen saturation on room air was 85 per cent.

The patient was removed from the respirator on July 17 , but did not maintain the above relatively satisfactory condition. In the course of the two following days the arterial $\mathrm{pCO}_{2}$ rose to 50 and then to $64 \mathrm{~mm}$. $\mathrm{Hg}$ while the $\mathrm{pO}_{2}$ descended to $28 \mathrm{~mm}$. $\mathrm{Hg}$ which gave a saturation of only 48 per cent on room air. The arterial-alveolar oxygen difference rose to $62 \mathrm{~mm}$. $\mathrm{Hg}$.

\footnotetext{
${ }^{2}$ Normal value in subject at rest, sitting, breathing room air at sea level : 5 to $14 \mathrm{~mm}$. $\mathrm{Hg}$.
}

It is of interest that on. the first day out of the respirator the patient exhibited no diminution in breathing upon administration of $90+$ per cent oxygen. Some 36 hours after leaving the respirator, the former response of diminution in breathing was again observed clinically, and this was confirmed the following day with more precise measurements.

The arterial $\mathrm{pH}$, which was on the acid side of normal with the patient on room air before respirator treatment, became alkaline during residence in the respirator, but fell to normal following administration of chlorides to the patient. Coincident to the administration of chlorides, the patient appeared to breathe better with the machine.

\section{DISCUSSION}

\section{Pathologic physiology}

A decrease in ventilation during administration of oxygen appears to have been observed first by Mosso (18) who described such a depression in animals anesthetized with morphine and chloral; this work has since been extended by others ( 8 , 19). Beddard and Pembrey (20) and Campbell, Hunt, and Poulton (21) described a similar ventilatory response in some patients with pulmonary and cardiac disease.

Barach and Richards (22) described this respiratory response to oxygen in a patient in whom the arterial $\mathrm{pCO}_{2}$ rose from 48 to $67 \mathrm{~mm}$. $\mathrm{Hg}$ during oxygen therapy. Similar results have been reported by Berconsky (23), Barach (24), Taquini and co-workers (25), and by Baldwin, Cournand, and Richards (5). Barach (2) has noted the ill effects of oxygen upon certain patients with emphysema and has recommended a gradual increase in percentage of inhaled oxygen. André (3) reviewed "apnea produced by oxygen" and concluded there was a case to be made for a multiple therapy including oxygen, carbon dioxide, analeptics, and artificial respiration provided the combination did not overtax the patient! Donald (6) has observed a patient with emphysema and heart failure who deteriorated into coma during oxygen therapy while the arterial $\mathrm{pCO}_{2}$ rose rapidly to $120 \mathrm{~mm}$. $\mathrm{Hg}$. After withdrawal of oxygen the $\mathrm{pCO}_{2}$ value fell rapidly and his general condition improved. Comroe, Bahnson, and Coates (7) reported eight patients with emphysema and chronic 
hypoxia who deteriorated mentally when given oxygen. An increase of $\mathrm{pCO}_{2}$ and a diminution in ventilation were accompanying features. All these patients initially had a $\mathrm{pCO}_{2}$ of $50 \mathrm{~mm}$. $\mathrm{Hg}$ or over and the phenomenon was seen in about half the patients who were found to have a $\mathrm{pCO}_{2}$ in excess of 50 . In two of these subjects, 10 per cent carbon dioxide was administered for sufficient time (five minutes) to raise the arterial $\mathrm{pCO}_{2}$ higher than it had been raised by the diminution in ventilation in response to oxygen; nevertheless, they did not become sleepy. Comroe rightly suggested that further observations would be required to determine the role of carbon dioxide narcosis.

Davies and Mackinnon (26) observed that a rise in cerebrospinal fluid pressure accompanied the phenomenon of diminished ventilation and described a similar rise when carbon dioxide was inhaled. Papilledema has been described in some patients with advanced emphysema (27).

Thus it is well established that a small proportion of patients with advanced emphysema have carbon dioxide retention and that when the partial pressure of carbon dioxide exceeds $50 \mathrm{~mm}$. $\mathrm{Hg}$ the administration of oxygen may affect the patient adversely. Deterioration is associated with a rising $\mathrm{pCO}_{2}$ and elevation of cerebrospinal fluid pressure. Recognition of the syndrome depends upon evidence of advanced emphysema and in addition these special tests : a lowered arterial oxygen saturation, a high value for carbon dioxide tension in the arterial blood and alveolar air, a diminution in ventilation and rise in $\mathrm{pCO}_{2}$ when oxygen is administered, and a poor ventilatory response to carbon dioxide.

It is not fully known how such emphysematous patients progress to the state of severe retention of carbon dioxide, but one likely factor is the element of airway obstruction present in many such cases. Some features of the pneumotachograph pattern of emphysema patients may be simulated by placing an obstruction in the airway of a normal subject; under these circumstances the work of breathing is plainly greatly increased.

Davies, Haldane, and Priestly (28) demonstrated the effect of anoxemia upon fatigue and failure of the respiratory center when there is resistance to breathing; they observed a rise in carbon dioxide tension during resistance breathing. This finding has been examined further by Cain and Otis (29) who remark that retention of carbon dioxide during resistance breathing indicates a compromise by the body; "the body tolerates some rise in carbon dioxide tension in preference to expending the effort that would be required to keep it at the original level." It is interesting to speculate whether pulmonary infections may contribute to the retention of carbon dioxide by diminishing muscular power, by increasing the work of breathing, or by reducing the sensitivity of the respiratory center.

\section{Physiologic basis of therapy}

The therapeutic objectives in cases of carbon dioxide retention are primarily three, to reduce the arterial $\mathrm{pCO}_{2}$ to normal levels by promotion of adequate ventilation, to maintain this level of ventilation long enough for the patient to adjust to the altered level of carbon dioxide, and to encourage him to maintain this increased ventilation.

Although in many emphysematous patients it may not be difficult to increase the ventilation greatly, it is advisable to proceed cautiously and to approach gradually the level required to maintain a normal $\mathrm{pCO}_{2}$. In this way there is sufficient time to permit adjustment of acid-base balance and to permit re-acclimatization of the respiratory center.

Acclimatization of the respiratory center has been observed at high altitude. Douglas and coworkers (30) showed that after ascent from sea level to Pike's Peak (barometric pressure $460 \mathrm{~mm}$. $\mathrm{Hg}$ ), the $\mathrm{pCO}_{2}$ fell immediately from an average of 39.3 to an average of $33.6 \mathrm{~mm}$. $\mathrm{Hg}$, and the $\mathrm{pO}_{2}$ from 104.7 to $48.4 \mathrm{~mm}$. $\mathrm{Hg}$. After six days at the summit, the alveolar $\mathrm{pCO}_{2}$ fell to $29.1 \mathrm{~mm}$. $\mathrm{Hg}$, and the $\mathrm{pO}_{2}$ rose to $53.5 \mathrm{~mm}$. $\mathrm{Hg}$. Rahn and Otis (31) made similar observations upon subjects acclimatizing at 9,500 feet; they further demonstrated, by means of breath-holding tests and carbon dioxide inhalation, an increased sensitivity of the center to carbon dioxide after acclimatization. In addition, the breathing of high oxygen mixtures caused no immediate change in the alveolar $\mathrm{pCO}_{2}$ and consequently no decrease in ventilation. Houston and Riley (32) found that subjects acclimatized to 22,000 feet maintained for four days a raised ventilation and lowered $\mathrm{pCO}_{2}$ when returned to sea level. Brown and associates (33) observed changes in ventilatory responses 
to carbon dioxide after normal subjects had been overbreathed for 24 hours in a body respirator.

Adaptation of normal subjects to a high carbon dioxide environment has also been observed. Schäfer (34) recorded the ventilation, $\mathrm{pCO}_{2}$, and $\mathrm{pH}$ in man during prolonged exposure to 3 per cent carbon dioxide. He noted a movement upwards of $\mathrm{pCO}_{2}$ and a diminution in sensitivity of the respiratory center; the latter was assessed by plotting ventilation responses to inhaled carbon dioxide and alveolar ventilation against $\mathrm{pCO}_{2}$. After an initial fall, the $\mathrm{pH}$ returned to normal levels. Otis (35) has investigated the impact on normal man of three days exposure to 3 per cent carbon dioxide. There was progressive inattention and listlessness and, following emergence, hypoventilation, a raised $\mathrm{pCO}_{2}$, and a diminished response to carbon dioxide, all of which gradually returned to normal.

Gray (36) has analyzed acclimatization on the basis of his multiple factor theory of respiration (37). After considering and rejecting factors other than the three chemical agents, hydrogen ion concentration, $\mathrm{pCO}_{2}$ and $\mathrm{pO}_{2}$, he notes the tendency of the first and last of these three to return to normal and concludes that changes in sensitivity to $\mathrm{pCO}_{2}$ are most likely since the $\mathrm{pCO}_{2}$ remains at an abnormal level. He remarks that the respiratory mechanism adapts itself to a prolonged disturbance in the $\mathrm{pCO}_{2}$ level by changes in sensitivity of such degree as to restore a normal response to the abnormal level of $\mathrm{pCO}_{2}$.

There is no dispute that high partial pressures of carbon dioxide are narcotic. Carbon dioxide has been used as an anesthetic agent both in normal (38) and psychotic patients (39). Dripps and Comroe (40) described occasional stupor in normal men breathing 10.4 per cent carbon dioxide for three to four minutes. The narcotic level in those with an already raised resting $\mathrm{pCO}_{2}$ has yet to be measured.

Theoretically there is a case for an attempt to assist in the excretion of retained carbon dioxide and to hold the patient at a normal arterial carbon dioxide tension until adaptation of the respiratory center to this tension has taken place. In both these patients it was possible to reduce the arterial and alveolar $\mathrm{pCO}_{2}$ to normal by artificial respiration although the second patient (J. M.) co-operated poorly with the methods employed. In the case of $\mathrm{N}$. G. the lowered $\mathrm{pCO}_{2}$ was maintained by his own efforts. Inhalation of 5 per cent carbon dioxide $11 \frac{1}{2}$ months later produced increments in ventilation and there was no longer a diminution in ventilation when oxygen was administered. Arterial oxygen saturations observed in the follow-up period were 92 per cent, compared with the 82 per cent seen in 1947. In the case of J. M., the lowered $\mathrm{pCO}_{2}$ level was not maintained by his own efforts. The first day after his period of artificial respiration there was no appreciable diminution in ventilation when oxygen was given; on the second day the $\mathrm{pCO}_{2}$ had risen and the oxygen diminution response was again seen.

The reasons for success of respirator treatment in one patient and failure in the other are not wholly clear. In the patient who later died, the level of carbon dioxide concentration was not nearly so high, and therefore contributed less to the total picture; the degree of cardiac and renal failure was pronounced and probably accounted for the fatal termination. Both patients were almost moribund when placed in a respirator. The one who eventually recovered was convinced, during relatively rational periods, that he was going to die and that the respirator would be to no small extent responsible. Nevertheless, the therapy was not given up, and eventually the remarkable improvement took place. It appeared likely, but could not be proved, that the change in carbon dioxide levels accounted for the dramatic reversal of the disease picture. It was, furthermore, expected that regression would soon occur; such was not the case although the patient received no breathing exercises or any further mechanical assistance. There were no significant changes in physical signs in the chest, in chest roentgenograms, or in pulmonary volume subdivisions. The long-lasting symptomatic improvement has appeared to be simply the result of an increase in pulmonary ventilation sufficient to maintain nearly normal gas exchange.

In the case of N. G. other possible causes of, or contributions to, his dramatic recovery have been considered. Pulmonary infection could not be definitely identified or ruled out, but was regarded as not a significant factor since the patient received substantial daily penicillin therapy throughout his hospital stay, the body temperature and erythrocyte sedimentation rate before and after 
respirator therapy showed no significant variation, and chest radiographs before and after respirator treatment showed no significant change. There was no evidence of pulmonary edema immediately prior to respirator treatment.

Amphetamine sulphate was administered daily between February 17 and March 29, 1950. This substance has been shown to be a mild respiratory and metabolic stimulant $(41,42)$, but termination of its use in this patient had no noticeable effect.

\section{SUMMARY}

1. A study of two patients with emphysema and carbon dioxide retention showed diminution of ventilation and elevation of $\mathrm{pCO}_{2}$ upon administration of oxygen, and no increment in ventilation when a mixture of 5.25 per cent carbon dioxide in oxygen was breathed.

2. Increase in lung ventilation brought about by use of a body respirator reduced the $\mathrm{pCO}_{2}$ to normal values in both subjects, while the arterial $\mathrm{pO}_{2}$ and oxygen saturations were markedly raised above previous levels.

3. Subsequent to respirator treatment one patient has for 12 months maintained his $\mathrm{pCO}_{2}$ at normal levels, and his responses to administration of high oxygen or carbon dioxide mixtures have been characteristic of the response of normal individuals. The other patient showed no diminution in ventilation while breathing oxygen in the immediate post-respirator period, but the improvement was very short in duration.

4. More impressive than the biochemical response in patient $\mathrm{N}$. G. was the clinical improvement which immediately followed the respirator treatment. After more than three years of severe headaches and marked exertional dyspnea, he became free of headaches and noted respiratory distress much less frequently. He returned to work, and at the present time has been at his job continuously for over nine months.

\section{REFERENCES}

1. Barach, A. L., Effect of low and high oxygen tensions on mental functioning. J. Aviation Med., 1941, 12, 30.

2. Barach, A. L., Impairment in emotional control produced both by lowering and raising the oxygen pressure in the atmosphere. M. Clin. North America, 1944, 28, 704.

3. André, M. J., L' apnée produite par l'oxygène (Mosso) et le traitment de la syncope par l'oxygène et le gaz carbonique. Presse méd., 1946, 54, 815.

4. Godfrey, L., Pond, H. S., and Wood, F. C., The Millikan oximeter in the recognition and treatment of anoxemia in clinical medicine. Am. J. M. Sc., 1948, 216, 605.

5. Baldwin, E. deF., Cournand, A., and Richards, D. W., Jr., Pulmonary insufficiency; study of 122 cases of chronic pulmonary emphysema. Medicine, 1949, 28, 201.

6. Donald, K., Neurological effects of oxygen. Lancet, 1949, 2, 1056.

7. Comroe, J. H., Jr., Bahnson, E. R., and Coates, E. O., Jr., Mental changes occurring in chronically anoxemic patients during oxygen therapy. J. A. M. A., 1950, 143, 1044.

8. Marshall, E. K., Jr., and Rosenfeld, M., Depression of respiration by oxygen. J. Pharmacol. \& Exper. Therap., 1936, 57, 437.

9. Scott, R. W., Observations on the pathologic physiology of chronic pulmonary emphysema. Arch. Int. Med., 1920, 26, 544.

10. Bert, P., La Pression Barométrique; Recherches de Physiologie Expérimentale. G. Masson, Paris, 1878. (Translated by Hitchcock, M. A., and Hitchcock, F. A.), College Book Co., Columbus, Ohio, 1943.

11. Brown, E. W., The physiological effects of high concentrations of carbon dioxide. U. S. Nav. M. Bull., 1930, 28, 721.

12. Seevers, M. H., The narcotic properties of carbon dioxide. New York State J. Med., 1944, 44, 597.

13. Silverman, L., and Whittenberger, J. L., Clinical pneumatochograph, in Methods in Medical Research, edited by Comroe, J. H. Jr. The YearBook Publishers, Inc., Chicago, 1950, Vol. II, pp. 104 and 215.

14. Gilson, J. C., and Hugh-Jones,. P., The measurement of total lung volume and breathing capacity. Clin. Sc., 1949, 7, 185.

15. Rahn, H., Moheny, J., Otis, A. B., and Fenn, W. O., Method for continuous analysis of alveolar air. J. Aviation Med., 1946, 17, 173.

16. Riley, R. L., Proemmel, D. D., and Franke, R. E., A direct method for determination of oxygen and carbon dioxide tensions in blood. J. Biol. Chem., 1945, 161, 621.

17. Van Slyke, D. D., and Neill, J. M., Determination of gases in blood and other solutions by vacuum extraction and manometric measurement. J. Biol. Chem., 1924, 61, 523.

18. Mosso, A., L'apnée produite par l'oxygène. Arch. ital. de biol., 1904, 41, 138.

19. Swank, R. L., and Foley, J. M., Respiratory, electroencephalographic and blood gas changes in prog- 
ressive barbiturate narcosis in dogs. J. Pharmacol. \& Exper. Therap., 1948, 92, 381.

20. Beddard, A. P., and Pembrey, M. S., Observations on pulmonary ventilation in disease. Brit. M. J., $1908,2,580$.

21. Campbell, J. M. H., Hunt, G. H., and Poulton, E. P., An examination of the blood gases and respiration in disease with reference to the causes of breathlessness and cyanosis. J. Path. \& Bact., 1923, 26, 234.

22. Barach, A. L., and Richards, D. W., Jr., Effects of treatment with oxygen in cardiac failure. Arch. Int. Med., 1931, 48, 325.

23. Berconsky, G., La función hemo-respiratoria en los "cardiácos negros de Ayerzá." Semana méd., 1933, 1, 1569.

24. Barach, A. L., Physiological methods in the diagnosis and treatment of asthma and emphysema. Ann. Int. Med., 1938, 12, 454.

25. Taquini, A. C., Fasciolo, J. C., Suarez, J. R. E., and - Chiodi, H., Respiration and circulation in pulmonary anoxemia. Arch. Int. Med., 1948, 82, 534.

26. Davies, C. E., and Mackinnon, J., Neurological effects of oxygen in chronic cor pulmonale. Lancet, 1949, 2, 883.

27. Simpson, T., Papilloedema in emphysema. Brit. $M$. J., 1948, 2, 639.

28. Davies, H. W., Haldane, J. S., and Priestly, J. G., The response to respiratory resistance. J. Physiol., 1919-1920, 53, 60.

29. Cain, C. C., and Otis, A. B., Some physiological effects resulting from added resistance to respiration. J. Aviation Med., 1949, 20, 149.

30. Douglas, C. G., Haldane, J. S., Henderson, Y., and Schneider, E. C., Physiological observations made on Pike's Peak, Colorado, with special reference to adaptation to low barometric pressures. Phil. $\mathrm{Tr}$. Roy. Soc., London, Ser. B, 1913, 203, 185.

31. Rahn, H., and Otis, A. B., Man's respiratory response during and after acclimatization to high altitude. Am. J. Physiol., 1949, 157, 445.

32. Houston, C. S., and Riley, R. L., Respiratory and circulatory changes during acclimatization to high altitude. Am. J. Physiol., 1947, 149, 565.

33. Brown, E. B., Jr., Campbell, G. S., Johnson, M. N., Hemingway, A., and Visscher, M. B., Changes in response to inhalation of $\mathrm{CO}_{2}$ before and after 24 hours of hyperventilation in man. J. Applied Physiol., 1948, 1, 333.

34. Schäfer, K. -E., Atmung und Säure-Basengleichgewicht bei langdauerndem Aufenthalt in $3 \% \mathrm{CO}_{2}$. Arch ges. Physiol., 1949, 251, 689.

35. Otis, A. B., Personal communication.

36. Gray, J. S., The multiple factor theory of respiration. III. Changes in sensitivity to $\mathrm{CO}_{2}$ in prolonged acapnia and hypercapnia. AAFSAM Research Project 386, Report No. 3, Nov. 21, 1945.

37. Gray, J. S., The multiple factor theory of the control of respiratory ventilation. Science, 1946, 103, 739.

38. Richardson, B. W., A synopsis of anaesthetics. Asclepiad, 1885, 2, 257.

39. Meduná, L. J., Carbon Dioxide Therapy. Charles C. Thomas, Springfield, Ill., 1950.

40. Dripps, R. D., and Comroe, J. H., Respiratory and circulatory response of normal man to inhalation of 7.6 and 10.4 per cent $\mathrm{CO}_{2}$ with comparison of maximal ventilation produced by severe muscular exercise, inhalation of $\mathrm{CO}_{2}$ and maximal voluntary hyperventilation. Am. J. Physiol., 1947, 149, 43.

41. Dill, D. B., Benson, O. O., Forbes, W. H., and Hall, F. G., Benzedrine sulphate (amphetamine) and acute anoxia; respiratory effects. J. Aviation Med., 1940, 11, 181.

42. Dill, D. B., Johnson, R. E., and Daly, C., Metabolic and cardiovascular effects of intramuscular injections of adrenaline and of amphetamine. Am. J. M. Sc., 1939, 198, 702. 